\title{
New media meets unschooled women:
}

A qualitative analysis of the use of new media by unschooled Kurdish women

Los nuevos medios se encuentran con mujeres no escolarizadas: un análisis cualitativo del uso de los nuevos medios por parte de las mujeres kurdas sin educación

Novas mídias encontram mulheres não escolarizadas: uma análise qualitativa do uso das novas mídias por mulheres curdas não escolarizadas

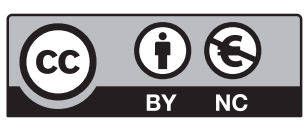

\section{Mehmet Sebih Oruç}

Akdeniz University (Turkey)

Research assistant at the Department of PR and Publicity at Akdeniz University's Faculty of Communication. He has a Master's degree in Public Relations from Marmara University, Istanbul, and is currently a Ph.D. student in the field of Public Relations and Publicity at Akdeniz University. His main topics of interest are new media and social change, philosophy of technology, critical theories and political communication. He published several articles on communication theories and post-truth.

sebih.oruc@hotmail.com

orcid.org/0000-0002-7695-2441

\section{Hediye Aydoğan}

Akdeniz University (Turkey)

Research assistant at the Department of PR and Publicity at Akdeniz University's Faculty of Communication. She holds a Master's degree in Public Relations and Publicity at Akdeniz University. She is now a PhD candidate in digital advertising studies. Her research interests include digital advertising, media literacy, research methods, and social media practices. She has so far published several studies on digital PR, digital advertising, and media and advertising literacy.

hediyeaydogan90@gmail.com

orcid.org/0000-0001-9696-8742

RECEIVED: October 10, 2020 / ACCEPTED: February 05, 2021

\section{Abstract}

This study is aimed to answer how and why illiterate and/or unschooled people use new media through in-depth interviews with 15 unschooled Kurdish women about general observations regarding city, media and people. It shows that these become an important part of people's daily life, and give them a new space 
to do things they could not do before. These do not make them more secular or modern, nor do they change their main attitudes and perspectives on life. However, these new media help them to preserve at least some of their traditional activities that are now under threat from recent capitalism and urbanization.

\section{KEYWORDS}

New Media, Social Media, Unschooled Women, Privacy, Daily Life.

\section{Resumen}

Este estudio tiene como objetivo responder cómo y por qué las personas analfabetas y / o no escolarizadas utilizan los nuevos medios a través de entrevistas en profundidad con 15 mujeres kurdas no escolarizadas sobre observaciones generales sobre la ciudad, los medios y las personas. Los resultados muestran que estos medios se convierten en una parte importante de la vida diaria de las personas y les brindan un nuevo espacio para hacer cosas que antes no podían hacer. Estos no las hace más seculares o modernas, ni cambia sus principales actitudes y perspectivas sobre la vida. Sin embargo, estos nuevos medios les ayuda a preservar al menos algunas de sus actividades tradicionales que ahora están amenazadas por el capitalismo y la urbanización recientes.

\section{PALABRAS CLAVE}

Nuevos medios, Redes sociales, Mujeres no escolarizadas, Privacidad, Vida diaria.

\section{Resumo}

Este estudo tem como objetivo responder como e por que as novas mídias estão sendo usadas por pessoas analfabetas e / ou não escolarizadas por meio de entrevistas em profundidade com 15 mulheres curdas não escolarizadas sobre observações gerais sobre a cidade, a mídia e as pessoas. A pesquisa mostra que eles se tornam uma parte importante da vida cotidiana das pessoas e Ihes dá um novo espaço para fazer coisas que não podiam fazer antes. Não os tornam mais seculares ou modernos, nem mudam suas principais atitudes e perspectivas de vida. Elas, entretanto, os ajudam a preservar pelo menos algumas de suas atividades tradicionais agora sob a ameaça do capitalismo e da urbanização recentes.

\section{PALAVRAS-CHAVE}

Novas mídias, Mídias sociais, Mulheres não escolarizadas, Privacidade, Vida diária.

\section{INTRODUCTION}

With a population of 82 million people, Turkey hosts nearly 60 million Internet users with a penetration rate of $72 \%$. With a total of 52 million active social media users, 44 millions of them access social media platforms on mobile devices according to the Report "Digital in 2019: Turkey" by We Are Social and Hootsuite (2019, p. 15). Therefore, it would not be wrong to refer to Turkey as a "social media lover" country (Alikilic \& Atabek, 2012).

Research suggests that people in Turkey spend an average of seven and a half hours of their time on the internet per day (We Are Social and Hootsuite, 2020, p. 43) and almost three hours of these are spent in social media activities (We Are Social and Hootsuite, 2020, p. 92). WhatsApp and Facebook are the most popular social media platforms in Turkey and the country ranks first in the usage of Instagram, with num 
ber of users equal to $57 \%$ of its total population (We Are Social and Hootsuite, 2020, p. 126). Nonetheless, there are times when people approach social media cautiously. In this sense, We Are Social and Hootsuite (2020, p. 67) reports that $58 \%$ of the total population in Turkey has some concerns regarding privacy and the misuse of their personal data. These concerns may hinder them from using social media as they may find it difficult to trust it.

After all this is considered, the following questions arise: What are people in Turkey doing on social media platforms while spending much of their daily time there? Can being unschooled and illiterate affect the use of social media? Does being an unschooled woman change how and why social media is used? In line with these questions, our study attempts to reflect on the social media usage of the unschooled women in the Eastern part of Turkey ${ }^{1}$ by carrying out in-depth interviews with fifteen unschooled Kurdish women.

\section{LITERATURE REVIEW}

Though it has being questioned in previous years, there are still "prevailing stereotypes of the silent, passive, and suppressed Muslim woman in the Middle East" (Schäfers, 2018, p. 4). But recently, this is changing with more comprehensive approaches. Still, when it comes to media and the issue of Muslim women, most of the studies (Gonzalez-Quijano, 1999; Maimuna, 1994; Purwaningwulan et al., 2019; Wellman \&

1 While the rate of the female illiterate people aged 15 or more is $17.2 \%$ of the global population in 2020 (We Are Social and Hootsuite, 2020), it is $6.1 \%$ of the total population of Turkey (TurkStat, 2018), located in the Southern Europe region with a high female literacy rate of $98 \%$ among women aged 15 and over (We Are Social and Hootsuite, 2020). This rate of illiterate female population in Turkey corresponds to $85.2 \%$ of the illiterate population in total.
Rainie, 2013) are either about social media and politics, or social media and economy. The general idea and conclusion that many academics reach about the women of the Muslim World and their social media usage is that new media has enabled these women participate more into social and civic life, and has empowered them by blurring the lines between public and private (Norton, 1999). However, the question on how these technologies affect these women's daily and social life and what they make of it is not really asked.

In such a scarcity of these kind of research, Elisabetta Costa's Book titled Social Media in Southeast Turkey: Love, Kinship and Politics (2016) has been important for this study. The book is based on 15 months of research during which Costa lived, worked and interacted with people of Mardin, a very similar city to the one addressed here, Dogubeyazit. Most of Costa's book is about issues like social media and youth, politics, romance, etc., but it pays little attention to what we are trying to find out with this research. However, it still contains insightful information. Therefore, we decided to use Costa's book to find about remaining and changing topics as almost 4 years have passed over her research. It also enabled us to determine parallels and changes.

\section{METHODOLOGY}

A qualitative research approach was used to answer the questions formulated in the introduction section. This approach was understood as an interpretive humanist paradigm and was based on the understanding and interpretation of reality (Creswell, 2007). A total of 15 in-depth interviews (with the approval from the institutional review board) with unschooled women were conducted using the purposive sampling method during the 'religious feast 
(Eid)' in 2019 through a semi-structured interview form based on Costa's study with adaptations to the scope of this research. Given the interpretative approach of the qualitative study, it allowed us to descriptively analyze experiences of the women interviewed, their use of social media and the effect of it on their daily life; which was not addressed before in the literature. Regarding the interviewees, the age range of the women interviewed was from 28 (youngest) to 53 (oldest), and the mean age was 35 years. Most of them were married (73,3\%) and were acquainted with the first author in informal talks before the study in order to get general observations. He also informed them of the data protection throughout the research and publication process.

\subsection{SATURATION POINT OF THE RESEARCH}

Glaser and Strauss define "saturation" in their ground-breaking work as the point when a researcher "sees similar instances over and over again, the researcher becomes empirically confident that a category is saturated" (1967, p. 65). Although it was developed for grounded theory, it is also useful for other qualitative researches (Townsend, 2013). The original idea was to carry out a total of 30 interviews in order to cover the different sensibilities, practices and topics. However, at the 11th and 12th interviews, we noticed that the information began to be repeated. Thus, we decided to continue until the 15th interview to confirm the repetition of the data.

\subsection{GENERAL OBSERVATIONS ABOUT CITY, LIFE AND SOCIAL MEDIA}

Doğubayazıt is in the eastern part of Turkey and has borders with Iran. Although it cannot be officially proven because different ethnicities are not recorded in Turkey, it is a well-known fact that the local inhabitants are all Kurdish. (The Editors of Encyclopaedia Britannica, 2020). Only governmental officials, some of the civil servants and military officials are from other parts of Turkey. Doğubayazıt has a new city life, which emerged especially in the last two decades as a part of the recent urbanization of eastern cities in Turkey and as a result of its increasing usage of new technologies (Costa, 2016).

When it comes to social media, it is easy to see that there is a clear division between old people and young people in their opinions about social media and its effects. The anxiety and suspicion about social media are very common among the middle-aged and elderly people in the city. They strongly believe that both male honor and female modesty are under threat as social media has become an inseparable part of the life of the new generations. As it was also observed by Costa in Mardin, some local events (like some hackers sharing women's "inappropriate" photos on the Internet) made many people stop using it (Costa, 2016). That explains why many women still do not use platforms like Instagram and Facebook, and are late-starters among the current users. For Doğubayazıt as well, the reason behind these ideas and less usage of social media has to do with some rarely seen events, among many other things. Three months before the researcher was there, a woman in one of the villages left her family to meet a stranger she contacted on social media while her husband was working in İstanbul. These kinds of events created tension, gossip and had strong repercussions in the perceptions of social media and its uses.

Referring to these events, many elderly and middle-aged men had strong and strict views about social media. "I would never, ever let my son marry a woman who uses the Internet", uttered one of those men. Some stated that 
these new technologies have made the new generation of girls more "unchaste". Probably because of this opinion, WhatsApp was the only application used by twelve of those interviewed. On the other hand, young men and women, secular or religious, perceive social networks as something that should be used. It has become a very important part of their life. WhatsApp is the most common and popular among different ages. Young and middle-aged people usually use Facebook and Instagram. As for the participants in this study, they all use WhatsApp, three of them also use Instagram and two participants also use Facebook.

\subsection{THEMES AND USAGES}

After collecting data, we were able to identify the most important topics to analyze the indepth interviews. We did not start with a prepared list of topics and tried to let it come out of the interviews. Some new questions were added to the interview as we discovered new topics and issues on the development phase. Though different thematization could be possible, we believed that the following topics were clear and insightful enough when we examined the interviewees: family and friends, daily life, ceremonies, new spaces, privacy and religion, gossiping and show-off.

\subsubsection{FAMILY AND FRIENDS}

Not surprisingly, family and friends were the most important reasons why these women used new media. The most frequently cited answer to our question "Why and how did you start to use social media?" was "because I have family members and friends far away from me". In fact, the oldest of the participants stated that the only reason why she uses mobile internet was because she wants to see her children and grand-children. That is also among the reasons why they use and like WhatsApp.
The use of platforms that usually form smaller and more private groups like WhatsApp and WeChat has been rising, especially in recent years. However, their impact has usually been underestimated and less studied, at least when compared to platforms like Facebook or Twitter (Miller, 2016). Definitely, the reasons why these platforms become popular and/or the way they are being used varies from culture to culture. For the Kurdish Community in Turkey, it is definitely because people do not want to lose family bonds.

Moving from rural areas to the urban areas and/or to big cities like Istanbul and Izmir, which increased during the late 1900s and early 2000s, contributed to the weakening of kinship solidarity and made many Doğubeyazıties lose connection with their relatives. The reason why WhatsApp is so important for them is because it enables them to be in touch with a higher number of distant relatives such as first, second or third cousins and/or old friends. Here is a reply of one of the participants to the question "Why and how did you start to use social media?":

During the early 2000s, I lost connection with many of my cousins and neighbor friends as they had to move to Istanbul. I was very happy when I was able to have a video conference with my dearest friend with whom I spent my childhood. That moment was great, I saw her children and we have been talking almost every day since then. That is something I could not imagine. WhatsApp is just wonderful. (K6)

Similar statements were repeated over and over again. Not only women, but also young boys stated that new media platforms are great because they can stay in touch with old friends and cousins. In short, what Costa obser- 
ved about the people of Mardin is equally true for Doğubeyazıties "So, while kinship networks are weakened in some respects, the impact of social media has been to strengthen such ties" (2016, p. 88).

The participants were literally fans of WhatsApp, and it is not so easy to find out specifically why it is the platform that they use the most. Costa argues that "WhatsApp conveys a sense of immediacy and privacy that is not provided by Facebook" when she tries to explain why it has become more popular among the Mardinets (2016, p. 97). It was easy to realize that relationships among group members are quite emotional and intense since they spend hours every day in interactions like sharing voice messages and pictures, and WhatsApp makes it possible for them. The participants usually informed that they like WhatsApp because it is very easy to use. The oldest woman of the study, K1 (53), started to use it four months before the interview in order to see her grandsons and granddaughters who live in Istanbul. She expressed: "I don't know much about the phone. First, I did not need it as my young girl was with me and she was showing me what I wanted, but when she got married, she taught me how to use it before she left home. I thought I would not be able to use it as I cannot read or write, but then I realized it is easy. Within time I learned some words".

Being a member of a WhatsApp group of cousins was something they usually mentioned. The size of WhatsApp groups is usually small, sometimes consisting of only sisters or nuclear family members, but in some cases including male and female cousins. Among these groups, "groups of female cousins only" seems to be the most important one for them. When asked what they talk about in these groups their answers were:
In the groups of female cousins only, everything is spoken. They ask questions, send holy Friday (religious gifs) messages, send their children's videos and pictures. Everything ... gossip, food,marriage, beauty... (K6)

Generally religious things, sometimes home labor or something else. If there is an engagement, a wedding or something. It's usually about singles, marriage and related things... that is what we are talking about. Everyday. (K11)

Showing their ability to cook well is also an important motivation here. They told the researcher that some days they just write and ask each other in the group to start a conversation by saying "Ok, let's share today's menu!" and everybody in the group share the menu. This sounds like a competition and the traditional border between public and private is crossed. They do it although they admit that it is not a good act to show what you eat in the Islamic and Kurdish culture. So, it is clear that traditional values are not strictly followed.

Spending time to check people's profile updates and pictures is very common as well. They aim to know more about the lives of their cousins, nieces, nephews, and, in case they use it, uncles and aunts. The interviewed woman (K8), who spends two or three hours a day on WhatsApp, was asked why she spends such long hours on the app and she stated that it was because her group mates keep sending voice messages and pictures and because she "does not want to miss anything about her relatives". Staying updated is crucial and they urge each other to stay always updated.

One of the most interesting findings of the field study was the discussion about "taking out of the group" some of their cousins because they do not get involved in group talks. One of the 
interviewees was threatened with being removed from the social media group and she was questioned about it. She was very shy and was not that beautiful to all people by the standards of the city and also of her distant relative. She was very upset about it. When she was asked why she does not participate, she responded: "I do not have a lot of time and I do not want to take photos and share them" That shows another face of these platforms: they create a new type of discrimination based on beauty and technology usage. These findings show that more studies are necessary to better understand private groups and related platforms.

In general, the online spaces enable these women to have certain nostalgias about family and friendship. When the researcher asked why they ask each other what they have in the menu for the particular day, the reply was standard: "because we were doing it back when we were living in the same neighborhood." It also gives a sense of intimacy. Seeking suggestions about new clothes or what to wear at a wedding ceremony or special days like Bayram (festive holiday) is also a very common practice, especially on WhatsApp and exactly as it was before internet when they were able to meet face to face. So, when it comes to family and friendship, social media not only reconnects these people, but it also creates a space to do much loved and missed practices.

\subsubsection{GOSSIPS AND SHOW-OFFS}

When the researcher was doing his field study and talking to people about social media, it was not so difficult to understand that gossiping is an important issue that has off-line effects. Although gossiping is considered both sinful and inappropriate in Doğubayazit, it is actually very common and everybody admits this. No matter what is the status, education or age, it is a part of people's lives, especially of those who do not have a job. Still, nobody would be willing to confess it. Therefore, as it may be expected, women did not want to talk about it (only three of them said it is one of their practices). However, it was very easy to understand that they do it secretly and that they use WhatsApp for it. For example, one of them (K3) said that they had to create a different group because their older aunty became the member of existing group, which means that they cannot speak about other (especially older) people. Part of another participant's answer to the question "What do you usually do?" was: "A little gossip (we do). We even set up separate groups for this"

Constant discussions, accusations and gossip cross the online space and affect their offline social life. Some women stop speaking with each other because of gossips, rumors and accusations from WhatsApp chats. In one case, even some relatives had a crisis because a woman has forwarded an audio message by other women to a third woman (who is accused or badly spoken about), and it had caused members of two families to stop seeing and communicating with each other. Therefore, it can be put forth that this usage has significant psychological and social side effects.

Behaving ostentatiously to impress other people is among the most important reasons why these women use social media. That means that social media creates an environment to show off, which is quite difficult for these women to attain as they live in a male dominated environment. Among other social media platforms, WhatsApp is crucial here again because creating other social media accounts is still considered to be inappropriate for married women and the traditional boundaries between private and public life are still strictly controlled and monitored. 
WhatsApp groups also offer a space for these women to share images that portray moments from their most personal and domestic lives, which have been private until now. Some of these women said, almost through the same sentences and the same body language (laughing), that they sometimes ask their "group friends" "to share a picture of them immediately, showing what they are doing and how they look". When asked if group members do it, they answered "most of the time". Therefo$r e$, it is clear that spontaneity is quite important but it is difficult to understand why. From what was observed, two motivations are clear and are also the most important ones. First, it makes them feel close. So close that they can see their immediate situations, and by this, they demonstrate that they give importance to their relationships. Secondly, photo-sharing and "basic" interactions make these acts more important. The fact that something is shared is enough to think that it is important, if not valuable.

These examples indicate how social media has transformed domestic and private daily life into an object of show-off. It has also opened, at least partially, these spaces to the gaze of others. However, there are still certain limits that no one breaks. Anything that might be related to sexuality is not considered appropriate to share.

\subsubsection{WEDDINGS}

Traditionally, weddings have been notable (if not the most) public events that men and women attend together and interact. They also create a space for women where they can be attractive. That is why, as Costa notes for Mardin, "Weddings were one of the very few occasions when women showed themselves in public to be chosen as brides by men or men's mothers, aunts or older sisters" (2016, p. 51). That is true for Doğubeyazıt as well. Nevertheless, since many people have migrated to big cities like Istanbul and Izmir, the traditional role of weddings in society has changed. Some of the Doğubeyazıties organize their wedding ceremonies in Istanbul because they want their relatives to participate, while some still choose their home city. However, this has caused a problem for these women because they are either looking for girls to help their singles get married or they are simply curious about what other people look like at the ceremony. However, how could they see other girls and the bride they wonder a lot about if the ceremony took place in Istanbul? Of course, via WhatsApp! Some of these women have downloaded WhatsApp only for that purpose: to see how people were dressed at the wedding ceremony, especially the bride.

The most conservative participant (K5) among them told the researcher that she did not like WhatsApp before, but she has now allowed her daughter (they use the phone together) to download it until she was convinced that it is the easiest and fastest way to see these pictures. So, like Mardin, "the reproduction of the wedding environment in these online spaces has been happening just when weddings are losing their social role in the offline world" (Costa, 2016, p. 51). One of the participants (K8) stated, "I usually look at the photos (on Instagram) because I have a brother for whom I want to find a girl to marry and I actually made him meet with the daughter of one of my distant relatives, but they did not agree (laughs)." Therefore, this clearly indicates that they use new media to perform some of the traditional activities: marriages are arranged via these platforms.

The word for wedding is among the most used words when we analyzed all the interviews. If there is a wedding that all group members know, there are long discussions regarding whether the bride is beautiful or not, whether the groom is handsome, young or looks elderly, 
who was the most beautiful one among girls, etc. These wedding discussions are so long that it is one of the few occasions when they share completely. Here are some examples:

... I rarely share. A wedding, or a special day of kids, etc. (K14)

If it is a wedding day, then there will be many audio messages in the group on that day that I will listen to.... We talk about brides, mothers-in-law, girls, grooms... (K12)

If there is an engagement, a wedding or something like that, we talk a lot about them. It's usually about singles or something like that (Laughs) ... (K11)

At that time, the wedding is the only issue. If anybody has gone to the wedding, we ask who was the most beautiful or whether the groom is a stranger. We ask about him and ask for their photos as well. (K7)

What these responses really show is that new media has changed people's lives, not by making them abandon their traditional activities and practices, but by changing the platform and the means. This is actually the case for many cultures and for many ancient/traditional practices (Miller, 2016). In fact, it has made some of the functions of these traditional activities (like finding a partner for their brothers, etc.) easier. So, contrary to what many people think (that new technologies make people more modern and that traditions lose their power as new technologies are being used more etc.) new media help these people to preserve and maintain many of their traditional practices in a time where they are under threat from uncontrolled and rapid urbanization.

\subsubsection{PRIVACY AND RELIGION}

We paid special attention to changes caused by social media on "the culture of privacy (mahremiyet, in Turkish)" The word mahremiyet, which is originally Arabic and means "forbidden", refers to "privacy, secrecy, intimacy, and domesticity". This is why it is difficult to find an exact word in English for it. It "always denotes confidentiality that the insider is expected to preserve and an outsider is expected not to violate" (Sehlikoğlu, 2015, p. 2). In short, anything that should be closed to a foreigner's gaze and knowledge is mahram (private). That means, at least in the eastern part of Turkey, anything that happens inside a house (like what you cook or what is the color of your curtain, etc.) is private. Thus, taking its broader meaning, we tried to see how social media changed the daily life of these people in general but specifically their private life.

Costa argues that "social media have to do with the redrawing of the boundaries between private and public in all these different domains of people's lives" (2016, p. 166), but what we will argue is that it has made people redefine the public and private. Something that is believed to be private in the offline world could be considered quite public in online world. Privacy is constantly redefined and remade on the basis of new normativity. The same people who do not let the smell of their barbecue reach the noses of their neighbors, because if they do not have it that will be inappropriate and it is not religiously right, see no problem in sharing it on WhatsApp. In fact, the questions "When do you share photos mostly?" and "What do you usually talk about?" led mostly to answers related to food:

We usually talk about what we have to eat, menu, where we go etc.... (K7) 
If you have a special meal, a picnic or something... they are shared on groups, especially the group of old friends. (K2)

New clothes, a wedding, and an interesting place I went to, an interesting meal I made, my children... (K1)

If I had a nice, special meal or a visit to a relative... (K6)

These examples show how social media changed domestic and private daily life, and transformed it into an object of show-off.

Among the most debated topics on social networks is that of man-woman relationships. Some extreme events such as a woman who eloped with a stranger she met on social media or a video of a woman in which she is naked that went viral when she tried to send it to her secret lover but accidentally sent it to another man, have caused that everyone in town is extremely suspicious about any kind of conversations between men and women online. There was no point of asking such questions regarding whether they have conversations with a foreign man or something as they would get offended and would not be very frank. However, we still were able to get some information about how they address this issue. For example, two participants (K6 \& K11) asserted that they created a different WhatsApp group around 6 months ago with around 50 members, all of whom were first cousins. All cousins, in her words, "who lived next to each other back when they were children but are now scattered across Turkey, so they can get back together". But just one week later, women created a new group with only female cousins, as they realized that they were not comfortable enough in the previous group and especially because they had to send audio messages since they are illiterate.
Furthermore, they stated that their all-female group was very active, while mixed groups were rarely used. However, this incident actually shows something strange: new media creates an even more rigid sex divide. This is because in the offline words, none of them would have any problem with talking to their male cousins. Nevertheless, as Costa also has elicited in her study, "gender segregation is even stricter in the images posted online than in behavior offline" (2016, p. 67). They are so afraid that even when they are all women, they fear that some of them might show their photos to men, which would not be very likely considering the general moral codes of the city. In this context, social media has multiplied the opportunities for producing new realities, but at the same time, it has intensified their vulnerability; something that has made many people suspicious of any type of use of new media. For instance, although not included into this research as they do not use any of these platforms, some women were proud to express that neither they nor their daughters use any kind of Internet platforms. A neighbor of the first author said, "Am I mad to let my children use these stupid things? We know what happens to girls who use it. Never ever!".

When it comes to religion, there are two important issues. The first one is about how often and in which ways religion or related issues are being spoken about. The second one is about how religion affects the use of these platforms. Four of fifteen participants stated that they "usually share religious stuff". This religious stuff can be a meme, a photo, a verse from Qur'an or some narrations from the prophet. Among all, a very interesting practice is to ask the ideas of others on religious matters. As one of the participants said, "Sometimes they ask questions like "what do you guys think about this religious issue?", and everyone expresses their 
opinion. Sometimes they argue because some women do not accept what Mulla says, and others say that we have to obey... We discuss a lot about 4-time-marriage. What would you do if it happened to you? Nobody wants that... (Laughs)...like this." That is actually interesting as it initiates discussions of religious issues in a more democratic way. Before new media, as it is well known and true for all Muslim countries, talking about religious matters and expressing one's own ideas were the privileges of men versed in Islamic studies. However, this has radically changed with the Internet and new media. This is not exclusive to women, but a social phenomenon of the Islamic world in general: traditional roles and interpretations are being challenged:

Accessible and cheap communication technologies and mass education feed the appetite for new media. Authoritative interpretations of Islam, long the preserve of learned men ('ulama'), are now in many hands. Indeed, some of the most creative thinking on Islam in recent years has been done by Muslim men and women with little or no formal training in Islamic jurisprudence (figh) or other specialties of the conventionally trained 'ulama. (Norton, 1999, p. 21)

Costa says about Mardin that "In conservative and less educated families, access to the internet is often prohibited to wives and daughters" (2016, p. 109), and "Not even educational purposes motivate parents to allow their daughters to use the internet" (2016, p. 109). Most probably, that was the situation in Doğubeyazıt back then (2016) as well. But now, we can say that it has changed, especially for more conservative families. The husband of one of the participants (K4) was a quite strict religious old man and his daughter used social media on a dai- ly basis. She told the researcher that she had problems with her husband at the beginning because she and her daughter really wanted to have a smartphone, but her husband used to see it as a threat. But now, he has got used to it thanks to the fact that they showed him that "Internet can be used for religiously informative purposes like easily finding the meaning of the verses of Qur'an or listening to religious speeches and speaking with grandchildren". In general, religion is among the most spoken issues among these women.

When it comes to how religion modifies the way they use these platforms, it is hard to know if it is religion or tradition that has the power to affect them. Taking this into consideration, we will use the term tradition to refer to the traditional understanding of religion. As it is usually accepted, a new "visio-sexual culture" emerged in the lives of the religious women in Turkey, especially with the emergence of new middle and upper class religious people, neoliberalism and new media (Sehlikoğlu, 2015, p.14). These women combine new western trends and luxury living with Islamic beliefs and dresses.

Presentation of the self in online spaces differs among religious women, especially between more moderate and ultra-religious ones. Almost all of them use social media to show off their new clothes, luxury goods, etc., but only to certain people. Nevertheless, this shows something new about public visibility of women in Turkey. WhatsApp has given these women a new opportunity through which they can show off and obtain the appreciation of at least one group of people, even a small group, without any sin and without turning their body into a showplace.

However, sharing photos on any online platform is believed to be inappropriate. None of them posts photos on Instagram or Facebook 
and sharing photos on WhatsApp is performed with caution. In this context, social media has multiplied the opportunities for producing new realities, but at the same time it has intensified people's vulnerability; something that has in turn given rise to many concerns over morality, including the morality of using these new online spaces (Costa, 2016, p. 79). Religion and family honor are the determining factors.

\section{DISCUSSION AND CONCLUSION}

Social media platforms serve several interests of people in their daily lives and the characteristics, beliefs and ways of living of these people can change how and why they use or don't use social media. Based on Costa's (2016) book on the usage of social media in the eastern part of Turkey, this study tries to reveal what has changed and stayed the same in terms of motivations, opinions and concerns of social media use in a similar city, Doğubeyazıt, while adding a new dimension into the core: being an unschooled woman. This study found that unschooled women use social media platforms, especially WhatsApp, not for new practices, but to perform old and lost practices.

Theoretically, the findings of this study are in parallel with Miller and Slater's argument about new media, particularly the concept of "expansive realization". Their argument can be summarized as follows: "people usually start to use new social media because they realize that they can do things that they wished to do but were not able. The Internet allows for an expansion of communication, but in this case, it is used to repair a discrepancy, thereby helping communities and people to come closer to a realization of who they already feel they "really" are." (2000, p. 178). It really seems to be the case for these women and explains why they love social media so much: it allows them to do some of their most beloved and forgotten practices that they were once able to do but were later frustrated due to rapid urbanization and capitalism. But, to what extent do they carry out these lost practices and what are the limits? That is a question for further studies.

Also, contrary to the well-known argument that modern technology brings new ways of life and modern perceptions, these people use new media in order to continue to do traditional activities, even though they have to use different means from previous generations for that. As we tried to show clearly, social media saved these traditions and connections. New media also help these women to build bridges with previous generations, continue their practices and preserve their functions. But the famous technological determinist question is still not answered: Does the use of a new medium change the "nature" of these activities and their meaning? This is a question that many speculations can be made about. This study showed that these people do not seem to be thinking that new media has changed the nature of their activities. One thing is clear, modern technology in general and social media in particular do not change their general approach to privacy and religious issues. The use of new media and new technologies does not lead to a more secular and modern perception of life.

Being one of the few studies on social media and their use by unschooled women, this research is expected to inspire more studies on how different groups in society (with some specific char acteristics) use social media in other contexts and how the use of social media can affect their lives and points of view. This type of study will show the different uses of new media and their relationship with user groups, which will help us overcome unproven generalizations. 


\section{REFERENCES}

Alikilic, O., \& Atabek, U. (2012). Social media adoption among Turkish public relations professionals: A survey of practitioners. Public Relations Review, 38, 56-63. https://doi.org/10.1016/j.pubrev.2011.11.002.

Costa, E. (2016). Social Media in Southeast Turkey: Love, Kinship and Politics. UCL Press.

Creswell, J. (2007). Qualitative Inquiry \& Research Design: Choosing among five approaches (2nd Edition). SAGE.

Glaser, B., \& Strauss, A. (1967). The Discovery of Grounded Theory: Strategies For Qualitative Research. Aldine Publishing Company.

Global Web Index Q1. (2017). GWI Social. Retrieved March 19, 2019, from https://insight.globalwebindex.net/hubfs/Reports/Social-Q1-2017/ GWI-Social-Summary-Q1-2017.pdf?t=1504263414218.

Gonzalez-Quijano, Y. (1999). The Birth of a Media Ecosystem: Lebanon in the Internet Age. (Trans. By D. F. Eickelman \& W. F. P. Raynolds). In: D. F. Eickelman \& J. W. Anderson (Eds.), New Media in the Muslim World: The Emerging Public Sphere (pp. 61-79), Indiana Univ. Pr.

Maimuna, H. (1994). Old Boundaries, New Visions: Women's Islamic Activism in Bangladesh. (Unpublished Senior Fellowship Program Thesis), Dartmouth College.

Miller, D. (2016). What is social media? In: D. Miller, E. Costa, N. Haynes, T. McDonald, R. Nicolescu, J. Sinanan, J. Spyer \& S. Venkatraman (Eds.), How The World Changed Social Media, (pp. 1-8), UCL Press.

Miller, D., \& Slater, D. (2000). The Internet: An ethnographic approach. Berg.

Norton, A. R. (1999). The New Media, Civic Pluralism, And The Struggle For Political Reform In: D. F. Eickelman \& J. W. Anderson (Eds.), New Media in the Muslim World: The Emerging Public Sphere, (pp. 61-79), Indiana Univ. $\operatorname{Pr}$.

Purwaningwulan, M. M., Suryana, A., Wahyudin, U., \& Dida, S. (2019). The Existence of Social Media as a Promotional Media in The Hijab Image RevoIution in Indonesia. Library Philosophy and Practice, 1-15.

Schäfers, M. (2018). "It Used to Be Forbidden": Kurdish Women and the Limits of Gaining Voice. Journal of Middle East Women's Studies, 14(1), 3-24. https://doi.org/10.1215/15525864-4296988.

Sehlikoglu, S. (2015). The Daring Mahrem: Changing Dynamics of Public Sexuality in Turkey. In: G. Ozyegin (Ed.), Gender and Sexuality in Muslim Cultures, (pp. 235-252), Ashgate. 
The Editors of Encyclopaedia Britannica. (2020). Dogubayazit. Retrieved January 11, 2020, from https://www.britannica.com/place/Dogubayazit.

Townsend, K. (2013). Saturation And Run Off: How Many Interviews Are Required In Qualitative Research?. Anzam Human Resource Management, $1-17$.

TurkStat. (2018). National Education Statistics Database: Population by Literacy and Sex 2008-2018. Retrieved October 11, 2019, from http://tuik.gov.tr/ PrelstatistikTablo.do?istab_id=1342.

Wellman, B., \& Rainie, L. (2013). If Romeo and Juliet Had Mobile Phones. Mobile Media \& Communication, 1(1), 166-171. https://doi. org/10.1177/2050157912459505.

We Are Social \& Hootsuite. (2020). Digital 2020: Global Digital Overview. Retrieved February 9, 2020, from https://wearesocial.com/digital-2020.

We Are Social \& Hootsuite. (2019). Digital in 2019: Turkey. Retrieved March 19, 2019, from https://wearesocial.com/global-digital-report-2019. 